\title{
GAYA KEPEMIMPINAN FAUZAN KHALID DALAM PENYELENGGARAAN PEMERINTAHAN DI KABUPATEN LOMBOK BARAT
}

\author{
Lalu Sopan Tirta Kusuma', Zulhadi* \\ Prodi Ilmu Pemerintahan, Fisipol Universitas Muhammadiyah Mataram \\ sasaku@gmail.com
}

\section{INFO ARTIKEL}

Riwayat Artikel:

Diterima: 20-04-2018

Disetujui: 21-06-2018

\section{Kata Kunci:}

Kepemimpinan

Fauzan Khalid

Pemerintahan

Lombok Barat

\section{ABSTRAK}

\begin{abstract}
Abstrak: Semakin menurunya kepercayaan publik (Public Trust) terhadap kualitas kepemimpinan di Indonesia, mulai dari level nasional hingga ke daerah menunjukan bahwa kualitas kepemimpinan kita saat ini sedang mengalami krisis. Kepemimpinan yang banyak menawarkan janji belaka sehingga membuat masyarakat seolah-olah bosan terhadap demokrasi yang melahirkan para pemimpin yang tidak berkualitas. Banyaknya kasus yang menjerat para komandan kepala daerah menunjukan bukti nyata bahwa kualitas para pemimpin kita saat ini masih belum mampu membawa masyarakatnya kepada kesejahateraan baik itu secara ekonomi, sosial, politik dan buadaya. Artikel ini secara khusus menguraikan dimensi masalah tersebut dan juga memberikan wawasan terkait dengan gaya kepemimpinan yang dilakukan oleh seorang Fauzan Khalid dalam penyelenggaraan pemerintahan di Kabupaten Lombok Barat, dimana ditengah keraguan dan krisis kepercayaan terhadap kepemimpinan kepala daerah, sosok Fauzan Khalid mampu menepis rasa pesimistis itu dengan menorehkan banyak prestasi yang luar biasa dalam memimpin daerahnya.
\end{abstract}

\section{A. LATAR BELAKANG}

Keberhasailan dan kegagalan suatu bangsa sangat ditentukan oleh sosok seorang pemimpin, sejak era reformasi bergulir pasca tragedi 1998 bangsa indonesia masih berada pada suatu krisis tidak hanya pada sektor perekonomian tetapi juga mengalami krisis kepemimpinan, mulai dari level yang paling atas yaitu presiden sampai gubenur, bupati/wali kota, camat, hingga kepada level pemerintahan yang paling bawah yaitu kepala desa tidak luput dari treck record buruk dalam memimpin pemerintahan pada skala kecil.

Kepemimpinan yang banyak menawarkan janji palsu membuat masyarakat bosan akan keberadaan demokrasi yang dimainkan oleh para elit politik, hal hasil masyarakat sudah tidak percaya kepada banyak para pemimpin, sehingga tidak heran ketika masa pesta demokrasi angka golput (Golongan Putih) masih tinggi. Ketidak percayaan masyarakat terhadap sosok pemimpin bukannya tanpa alasan, banyaknya pemimpin yang lebih mementingkan kepentingan kelompok daripada kepentingan publik menjadi salah satu alasan, kenapa masyarakat tidak percaya kepada pemimpin. Janji pada saat kampanye cenderung di khianati ketika sudah memegang tangguk kekuasaan, sehingga membuat rakyat menjadi bosen dan muak melihat tingkah laku para pemimpin yang sama sekali tidak peduli akan nasib rakyat yang sudah membawa mereka kepada singasana yang kekuasaan.

Salah satu figur seorang pemimpin yang dianggap mampu menepis keraguan dari banyak kalangan terkait dengan prestasi kepemimpinannya adalah Fauzan Khalid Bupati Lombok Barat. meskipun pada awal masa kepemimpinanya banyak kalangan meragukan akan kemampuan dari pemimpin yang terkenal dengan pluralisme dalam segala hal ini. Berkat ketekunan dan keuletan Fauzan Khalid untuk menjadi pemimpin yang revulusioner terbukti dari banyak prestasi dan terobosan yang dilakukan pada masa kepemimpinanya yaitu:

1. Pertama, Fauzan Khalid meraih penghargaan inpirator pembangunan daerah pada tahun 2017.

2. mampu menyelaraskan kehidupan umat beragama yang ada di lombok barat, sehingga kehidupan pluralisme dan toleransi menjadi penguat dalam penyelenggaraan pemerintahan.

3. Ketiga, pada masa kepemimpinanya Fauzan Khalid juga kerap melakukan kerjasam dengan NGO internasional

Apa yang sudah dilakukan oleh Fauzan Khalid dalam menjalankan roda pemerintahan di Lombok Barat sesuai dengan semangat Nawacita Presiden Jokowi yaitu membangun Indonesia dari daerah dan pinggiran. 
Berdasarkan uraian di atas, diperlukan sebuah kajian secara mendalam untuk menganalisa dan mengetahui gaya kepemimpinan apa yang digunakan oleh Fauzan Khalid dalam menjalankan roda pemerintahan di Kabupaten Lombok Barat? sehingga diharapkan natinya peneliti mampu menjelaskan faktor-faktor apa saja yang mempengaruhi kepemimpinan Fauzan Khalid di Lombok Barat.

\section{B. METODE PENELITIAN}

Dalam penelitian ini, peneliti menggunakan pendekatan kualitatif. pendekatan kualitatif yaitu suatu prosedur penelitian yang menghasilkan data deskriptif berupa kata-kata tertulis atau tulisan dari orang-orang dan perilaku yang dapat diamati”. ${ }^{1}$ Pendekatan ini digunakan karena peneliti merasa bahwa ada kesesuaian antara permasalahan yang dibahas dengan tujuan yang ingin dicapai dalam penelitian ini. Di mana peneliti akan membahas tentang gaya kepemimpinan Fauzan Khalid dalam penyelenggaraan pemerintahan di Kabupaten Lombok Barat.

Metode penentuan subjek dalam penelitian ini adalah menggunakan Snowball sampling. Snowball sampling adalah metode penentuan sampel dengan cara mengambil secara langsung dari sejumlah subjek penelitian yang ada 2 . Penentuan subjek penelitian dengan menggunakan metode ini dengan memilih subjek penelitian kepada orang-orang tertentu saja, seperti Bupati Lombok Barat, dinas terkait, kelompok tani, dan ketua forum kerukunan umat bergama di Kabupaten Lombok Barat.

Pengumpulan data merupakan prosedur yang sistematis dan juga merupakan standar untuk memperoleh data yang diperlukan. Dalam hal ini pengumpulan data ini menggunakan metode-metode sebagai berikut: Metode Wawancara (interview), Metode pengamatan (observasi), dan Metode dokumentasi .

\section{HASIL DAN PEMBAHASAN}

\section{Kepemimpinan Transformatif Fauzan Khalid Dalam Penyelenggaraan Pemerintahan Di Kabupaten Lombok Barat}

Era reformasi harus kita akui membawa dampak yang sangat positif terhadap perubahan bangsa, salah satu yang nyata kita rasakan adalah otonomi daerah, dimana ruang dan peluang yang dulunya digengam kuat oleh pemerintah pusat melalui kekuatan sentralistis kekuasaan dan kewenangan perlahan bisa diseimbangkan melalui pelimpahan kewenangan melalui asas desentralisasi, dekonsentrasi dan medebewind. Dengan diberikanya sebagian kewenanagan melalui asas desentralisasi tersebut pemerintah daerah harus mampu berfikir keras untuk memberikan kesejahteraan kepada masyarakatnya dengan berbagai macam kebijakan

\footnotetext{
${ }^{1}$ Lexy J.M. Penelitian Kualitatif, Jakarta: PT. Rineka Cipta,2010

2 Arikunto, Suharsimi, Metodologi Penelitian Suatu Pendekatan Praktik, Jakarta: Rineka Cipta, 31:2010
}

dan program yang pro kepada rakyatnya. Pemerintah daerah di tuntut harus mampu mejawab tantangan dan persoalan bangsa yang sangat Complicated seperti, persoalan tentang kemiskinan, penganguran, kriminalitsas, dan masih banyak lagi persoalan yang perlu mendapatkan perhatian secara serius oleh pemerintah pusat maupun daerah.

Perubahan dan persoalan yang terjadi diberbagai daerah pasca era otonomi daerah harus juga diimbangggi dengan perubahan paradigma para pimpinan daerah sesuai dengan kebutuhan dan kondisi real di tiap-tiap daerah. Sehingga kepala daerah dalam melaksanakan tugasnya tidak jauh dari rel yang sudah digariskan untuk kemajuan dan kesejahteraan daerah.

Seperti apa yang sudah dilakukan oleh Fauzan Khalid dalam memimpin Kabupaten Lombok Barat. Apa yang sudah dilakukan oleh Fauzan Khalid pada masa kepemimpinannya sebenarnya bukanlah sesatu yang baru didalam teori kepemimpinan dan banyak dilakukan oleh kepala daerah lainya di Indonesia. Namun kesederhanaan dalam memimpin Lombok Barat sesuai dengan apa yang menjadi kebutuhan masyarakat setempat adalah kunci sukses Fauzan Khalid dalam memimpin daerah yang berbatasan dengan Kota Mataram ini.

Dalam melaksanakan setiap kebijakanya Fauzan Khalid melakukan pendekatan secara musyawarah persuasif kepada masyarakat karena budaya masyarakat Lombok Barat mengedepankan asas kekeluargaan dalam menjalankan kehidupan berbangsa dan bernegara. Berikut dapat dilihat gaya kepemimpinan Fauzan Khalid di lihat dari aspek Transformatif :

\section{a. Partisipasi}

Dalam mengimplementasikan kebijakan pemerintahan Fauzan Khalid tidak menggunakan gaya otoriter untuk memutuskan keputusan melainkan memberikan ruang kepada seluruh wargga masyarakat atau stakholder. Bagaimana kepemimpinan Fauzan Khalid tidak semata-mata hanya sebatas menjalankan amanah undangundang yang kemudian di breakdown menjadi kebijakan dan program, namun setiap kebijakan ataupun keputusan yang diambil berdasarkan kepada kondisi dan situasi pada saat itu.

Kabupaten Lombok Barat adalah salah satu daerah yang memiliki potensi pariwisata pantai sengigi, sehingga tidak heran disepanjang jalan diwilyah sengigi berjejer para pedagang kaki lima, yang selama masa kepemimpinan Fauzan Khalid tidak terjadi permasalahan terkait dengan persoalan penertiban para pedagang kaki lima. Berikut petikan wawancara dengan Ketua APLKI Lombok Barat: 3

"Fauzan Khalid orang-orangnya biasa-biasa saja, berpihak kepada rakyat termasuk juga kepada para pedagang kaki lima. Bentuk keberpihakan beliau kepada para pedagang kaki lima adalah pemberdayaan melalui Dinas Peridustrian dan Perdagangan, meliputi: Pelatihan-pelatihan, Pemberian bantuan, seperti: Gerobak jualan, rombong jualan dan tenda.

\footnotetext{
3 Wawancara dengan Bapak Mukril Hakim, S.IP, Ketua APLKI di Kabupaten Lombok Barat, Tanggal 7 Februari, Jam 16:23 Wita.
} 
Strategi yang dilakukan oleh beliau adalah mengedepankan langka antisipasi terhadap segala sesuatu yang mungkin akan terjadi, proses musyawarah dalam mengambil keputusan juga faktor penentu keberhasilan Fauzan Khalid dalam memimpin daerah lombok Barat. Fauzan Khalid sangat menjunjung tinggi tradisi partisipatif dan bahkan sebelum menjabat menjadi Bupati Lombok Barat juga terlihat sosoknya yang selalu mengedapnkan prinsip partisipatif dalam setiap pekerjaan yang digeluti mulai dari ketika menjadi Ketua KPUD NTB. 4

\section{b. Rule Of Law}

Penegakan hukum adalah salah satu ciri khas dari kepemimpinan Fauzan Khalid sehingga dalam menjalankan roda pemerintahan sangat konsisten baik itu aturan yang menyangkut tentang penertiban PKL ataupun hal yang menyangkut ada dari para pegawai atau staf yang melakukan kesalahan maka dia akan mengambil tindakan tegas. Pada masa kepemimpinannya masyarakat sudah merasakan tegaknya aturan yang dilakukan oleh kepemimpinan Fauzan Khalid dalam memimpin Lombok Barat. inilah salah satu faktor yang membuat Fauzan Khalid familiar dimata masyarakat karena sudah terbukti bahwa bahwa dalam proses penegakan hukum tidak pandang bulu dan benar-banar memegang asas keadilan (justice).

\section{c. Transparancy}

Era modern seperti saat ini, kepemimpinan suatu rezim wajib mengedepankan asas transparancy atau keterbukaan dalam mengelola sebuah negara ataupun daerah, Fauzan Khalid menerapkan asas transpanransi atau keterbuan dalam menjalanakan dan mengelola Lombok Barat, seperti membahas anggaran yang dilakukan secara terbuka dan semua orang boleh mengetahui jumlah anggaran dan peruntukannya untuk apa saja, dan juga boleh diliput oleh media pada saat pembahasaan. Pembahasaan anggaran secara terbuka adalah salah satu ciri khas kepemimpinan Fauzan Khalid, karena memang selama ini terkait dengan anggaran biasanya dilakukan pembahasaan secara tertutup.

\section{d. Responsivines}

Sebagai orang nomor satu di Lombok Barat Fauzan Khalid kerap mengunjungi wargga masyarakat baik itu yang ada aduan ataupun tidak ada aduan dari masyarakat beliau tetap melakukan blusukan ke masyarakat untuk megetahui kondisi real dari setiap wargga masyarakat.

\section{e. Accountability}

Setiap kebijakan dan program kerja yang diimplementasikan oleh Fauzan Khalid dapat diketahui secara utuh oleh masyarakat sebagai bentuk pertanggungjawaban pemerintahan kepada publik.

\section{f. Equality}

4 Ahkam Mahfudz, Pemimpin Jamaq-jamaq, penerbit, Suara Lombok Barat Bangkit Bagian Humas dan Protokol Sekretariat Daerah Kabupaten Lombok Barat,., 112: 2017
Sebagai seorang pimpinan wajib menjamin dan memberikan kesempatan yang sama kepada wargga masyarakatnya untuk memproleh keadilan dan kesejahteraan yang merata dan memadang golongan dan kelas mereka. Proses perekrutan pegawai di lingkungan daerah Kabupaten Lombok Barat dilakukan dengan berdasarkan kepada regulasi yang sudah ada sehingga terhindarkan dari praktek-praktek budaya korupsi, kolosu dan nepotisme (KKN).

\section{Menata Manajemen Pemerintahan Dengan Gaya Kepemimpinan Jamaq-Jamaq}

Dalam menjalankan roda pemerintahannya Fauzan Khalid tidak neko-neko dalam menafsirkan setiap kebijakan dan regulasi yang diamahkankan oleh undang-undang dan instruksi dari pusat. Prinsip-prinsip yang dikedepankan dalam memimpin Lombok Barat seperti yang sudah dijelaskan di atas adalah, patisipasi, rule of law, transparansi, responsivines, acountability, dan equality. Semua prinsip kepemimpinan modern seperti saat ini dijalankan secara apa adanya oleh Fauzan Khalid.

Prinsip apadanya dalam memimpin dan mengelola Lombok Barat dikenal dengan istilah Jamaq-jamaq adalah sebuah ungkapan dalam bahasa Ibu (Mother Tonge) Fauzan Khalid, yaitu bahasa susuk sasak. Kata itu memili banyak arti. Bisa jadi artinya apa adanya tidak mengada-ada "tidak dibuatbuat" sederhana atau bahkan untuk menunjukan sesuatu itu "benar-benar tersirat (implisit) juga secara tersurat (eksplisit), bisa juga diartikan sebagai konsistensi antara yang nampak dengan yang tidak nampak. 5

Artikulasi itu banyak ditemui sebagai predikat yang disematkan oleh banyak orang kepada Fauzan Khalid. Dia jamaq-jamaq, komentari itu datang dari banyak komentar itu datang dari banyak kalangan, baik dari kebanyakan orang (umum), kepala desa sampai kepada kepala dusun, para ustadz dan tuan Guru, dan bahkan dari kalangan birokrat yang biasanya sering terkena status "jamaq-jamaq" itu.6

Dari hasil wawancara dengan Tuan Guru (kiayi orang sasak) yang diwawancaraipun menyimpulkan hal yang sama, Fauzan Itu Jamaq-jamaq. 7

Menurut penuturan salah seorang penulis (Ahkam Mahfudz), 8 bahwa Fauzan Khalid miripmirip dengan Almarhum pak Iskandar, tutur Haji Muhammad Taufik membandingkan gaya kepemimpinan Fauzan Khalid dengan para Bupati yang dikenalnya. Dimana Fauzan sangat memberikan kepercayaan kepada bawahanya.

Hasil wawancara dengan Ketua APKLI Kabupaten Lombok Barat juga, menuturkan hal yang sama yaitu:

Beliau dalam menjalankan roda pemerintahan di Kabupaten Lombok Barat, sangat sederhana, tidak terlalu protokoler, siapa saja boleh menemui beliau, mulai dari masyarakat yang paling bawah sekalipun

\footnotetext{
${ }^{5}$ Ahkam Mahfudz, Pemimpin Jamaq-jamaq, penerbit, Suara Lombok Barat Bangkit Bagian Humas dan Protokol Sekretariat Daerah Kabupaten Lombok Barat, 94:2017.

${ }^{6}$ Ibid, 95

${ }^{7}$ Wawancara dengan Tuan Guru H, Salman, Kamis, Tanggal 22 Februari, Jam 10:14 Wita.

${ }^{8}$ Opcit112
} 
sampai pada masyarakat level atas, penampilanya juga jamaq-jamaq (sederhana) seperti bukan seorang pejabat, dan bahkan dalam sehari semalam bisa mengunjungi masyarakat secara langsung apabila tidak keluar daerah, lewat sms juga beliau bisa dihubungi.

Pendekatan partisipatif memberikan nuansa kerja yang baru di lingkungan birokrasi pemerintahan di Lombok Barat. Budi Dharmanjaya 9, salah seorang kepala SKPD menuturkan bahwa gaya kepemimpinan Zaini Arony dengan gaya kepemimpiann Fauzan Khalid terhadap para jajaran bawahanaya. Kalau di zamannya pak Zainy Arony, beliau memberikan arahanya sangat detail, jadi kita kurang kreatif untuk mengeluarkan kemampuan karena takut keluar dan dianggap salah. Berbeda dengan pak Fauzan. Sekarang ini dia selow (mungkin bisa diartikan tidak terlalu intervensi. Cukup lapor, maka kita sudah bisa memulai kerja, kalaupun diberikan arahan cukup yang umum-umum saja, yang penting aman.

Fauzan khalid sangat menghargai kemampuan teknis anak buahnya, sehingga ia tidak terlalu inggin mencampuri bagaimana sebuah program tersebut terlaksana, yang penting target tujuan, dan sasaran tercapai.1o Meskipun diberikan kesempatan kepada anak buahnya untuk melakukan pengembangan terhadap pekerjaan, namun beliau sangat mewantiwanti jajaranya untuk bekerja sesui dengan prosedural sehingga bisa aman dari aspek penegakan hukum sebagaimana beliau bekerja sesuai dengan regulasi yang ada.

Istilah jamaq-jamaq yang selama ini melekat kepada sosok Fauzan Khalid bisa dilihat dari cara atau sikapnya melakukan pendekatan yang selama ini mengandalkan "pendekatan personal", sehingga kerap bergantung pada sisi personal/pribadi si kepala SKPD yang memiliki motivasi kerja yang tinggi. Maka pendekatan partisipatif ini membuatnya leluasa untuk bekerja memenuhi target dengan segala macam bentuk kreativitas da inovasi. Terbukti dengan pengembangan kinerja beberapa SKPD yang mengalami lonjakan prestasi cukup tinggi.

Jamaq-jamaq jika dilihat dari prinsip pembangunan partisipatif kepemimpinan Fauzan Khalid yaitu semanagat kebersamaan dan gotoroyong. Fauzan ingin menghapuskan mentalitas kerja yang ego-sektoral. Bagi Fauzan setiap pekerjaan yang diemban adalah dalam rangka pekerjaan yang lainnya. Setiap sektor adalah terkait dengan sektor yaang lainnyas sehingga hasil sektoral adalah terkait dengan sektor lainnya sehingga hasil dari sektor itu tidak akan pernah berlaku hanya untuk sektoral itu. Semua sektor secara struktural atau non struktural saling mempengaruhi.

Sebagai contoh, sektor ekonomi tidak akan pernah bisa membaik bila tidak ditopang oleh sektor pendidikan dan kesehatan, politik dan keamanan, bahkan budaya. Begitu pula sektor kesehatan tidak akan mencapai derajat yang sehat apabila tidak didukung oleh pendidikanm ekonomi, kemanan, politik, dan lain sebagainya. Selalu saling topang satu dengan lainnya. Dengan demikian bagi Fauzan,

\footnotetext{
${ }^{9}$ Ibid, 113

${ }^{10}$ Hasil wawancara dengan Bapak Fauzan Khalidz, pada tanggal, 25 Januari, jam 13:24 Wita, 2018
}

ketika sektor itu menjadi tugas dari salah satu SKPD, maka tugas tersebut terkait dengan SKPD lainya. Bila ia berhasil, maka keberhasilanya bukanlah keberhasilan SKPD itu sendiri. Jangan ada claim keberhasilan.

Hal praktis dalam manajemen kepemimpinan jamaq-jamaq adalah distribusi kewenangan (distribution of power), sososk Fauzan Khalid yang terkenal dengan Jamaq-jamaq melahirkan gaya kepemimpinan dan tata kelola pemerintahan yang unik. Bagi sisapapu yang menyukai hal-hal yang bombastis model tata kelola ini tidak menonjol. Sulit dinilai, dan bahkan tidak ada apa-apanya. Namun yang mengalami langsung sebaga subjek, tata kelola ini seperti menyentuh hal yang mendasar dari mereka, seperti inisiatif menjadi lebih terbuka, potensi yang berkembang, tradisisi kerja yang inovatif dan berfikir yang "out of box" yang tercermin dalam proses kerja sehari-hari.11 Dalam manajemen modern, tata kelola sebuah organisasi tidak berpusat pada pemimpin (leader) pemimpin mendelegasikan tugas dan kewenanaganya tetap tetap melakukan pengawasan. Dalam manajemen modern itupun, keputusan tidak hanya datang dari seseorang saja, namun berlaku asas musyawarah yang kolektif dimana keputusan yang diambil adalah didominasi menurut pandangan dari yang akan menjalankan dan ahlinya.

Dalam menjalankan program pemerintah dimasa kepemimpinanya dia lebih mengedepankan program yang berdampak secara langsung kepada masyarakat. Untuk itu, Fauzan lebih memilih program yang langsung memberi manfaat terhadap target-target mikro dalam pemangunan yang mampu mengentaskan kemiskinan. Sebelum masa kepemimpiannya bahwa angka kemiskinan di lombok Barat ada di angka $17,38 \%$. Saat inipun angka kemiskinan itu menuurun menjadi $16,73 \%$ atau sekitar 103 ribuan yang diupayakan turun lagi 1\% di tahun 2018. Penurunan angka kemiskinan itupun didukung dengan Gini Rasio (jarak miskin-kaya) yang hanya 0,27 point dan terbaik di NTB dengan kedalaman kemiskinan sebesar 3,11 point dan keparahnya hanya mencapai o,89.12

Percepatan pembangunan (shortfall) yang menjadi kunci keberhasilan pembangunan di Lombok Barat di dua tahun terakhir di mana pemerintah Kabupaten Lombok Barat mampu mencapai 3,03 dan terakhir 2,63 dan rata-rata 2,09 setiap tahun. Demikian juga dengan pertumbuhan ekonomi yang mencapai $5,73 \%$ jauh di atas nasional yang mencapai $5,02 \%$ yang bearti masyarakat Lombok Barat lebih mampu lagi untuk meningkatkan kesejahteraanya. Saai inipun distribusi pendapatan semakin merata dan Kabupaten Lombok Barat mencapai penurunan angka penganguran terbuka paling baik selama 5 tahun terakhir, yaitu hanya 10.749 orang atau $3,28 \%$ terbaik se-NTB dan jauh di bawah angka nasional sebesar 5,50\%.

Semua hasil pembangunan yang dicapai oleh Kabupaten Lombok Barat terekam dalam Indeks Pembangunan Manusia (IPM) yang memiliki trens meningkat setiap tahunya. Untuk diketahui secara

\footnotetext{
${ }^{11}$ Opcit, 119

${ }^{12}$ Opcit, 126
} 
komulatif ranking, Kabupaten Lombok Barat pernah berada pada ranking 8 dari 10 Kabupaten Kota seNTB, namun pada tahun 2016, melonjak tajam menjadi ranking keempat yang kemudian mampu dipertahankan sampai pada tahun 2017.

Dalam rangka itu, Fauzan sangat konsern terhadap program-program kerja yangb berkaitan langsung dengan target yang dicapai, terutama sejatinya adalah pengentasan kemiskinan. Bagi sosok Fauzan, kemiskinan adalah alasan berjalannya pemerintahan dan pembangunan. Tidak adan manfaatnya negara memiliki sistem pemerintahan dan aparatur apabila persoalan kemiskinan menjadi isu strategis. ${ }^{13}$ Berikut dapat dilihat contoh program langsung Fauzan Khalid:

TABEL 1.

PROGRAM LANGSUNG KEPEMIMPINAN FAUZAN KHALID

\begin{tabular}{lll}
\hline NO & \multicolumn{3}{c}{ Program Langsung Kepemimpinan Fauzan } \\
\multicolumn{3}{c}{ Khalid } \\
\hline 1 & $\begin{array}{l}\text { Perlakuan Khusus untuk Industri } \\
\text { Menengah }\end{array}$ \\
2 & $\begin{array}{l}\text { Memperhatikan kesehatan Reproduksi } \\
\text { Kesehatan Ibu dan Anak }\end{array}$ \\
3 & $\begin{array}{l}\text { Mendorong kinerja para tenaga Kependidikan } \\
\text { dan Guru Tidak Tetap }\end{array}$ \\
4 & Pembangunan Infrastrktur \\
5 & Memperkuat Industri Pariwisata \\
\hline
\end{tabular}

Sumber: Humas Kabupaten Lombok Barat, 2017.

Berdasarkan data program kepemimpinan Fauzan Khalid di atas dapat dilihat bahwa focusnya pembangunannya adalah implementasi dari program secara langsung dan bersentuhan dengan masyarakat.

Pertama, program pemberlakukan khsusus untuk industri kecil menengah dengan mengupayakan perputaran uang APBD ke APBD, dimana Fauzan megajak kesemua jajaran birokrasinya untuk membudayakan dan mentauladankan menjadi terdepan dalam membelanjakan uang kepada pelaku usaha dari para pengusaha lokal. Keseriusan itu, Bupati Fauzan Khalid menerbitkan Peraturan Bupati Nomor 21 tahun 2017 tentang penggunaan produk lokal unggulan daerah dan instruksi yang mengwajibkan jajaran SKPD membelanjakan anggarannya untuk masyarakat lokal.

Kedua, memperhatikan kesehatan Reproduksi Anak serta kesehatan ibu dan anak, Fauzan sangat memperhatikan sektor kesehatan sebagai pilar pembangunann manusia, dengan mendorong Dinas Kesehatan, dan Pemberdayaan Masyarakat dan pemerintahan Desa, Fauzan meletakan dasar kerja koordinatif antar semua elemen untuk ikut serta secara aktif dalam pembangunan kesehatan di Lombok Barat.

Ketiga, Mendorong kinerja para tenaga Kependidikan dan Guru Tidak Tetap, pasalnya semenjak ditetapkan dan dilantik menjadi Bupati Lombok Barat, Fauzan Khalid sangat memperhatikan khusus ke dunia pendidikan terutama dalam konteks Sustanable Development Goals (SDG"s) yang

${ }^{13}$ Ibid, 127. menjadi tres pembangunan akhir-akhir ini. Dalam pendekatan itu, perhitungan efektivitas pembangunan di bidang pendidikan dihiutung berdasarkan rata-rata lama sekolah (means years of scholling) dan harapan lama sekolah (expected years of scholling). Pada angka rata-rata lama sekolah, Kabupaten Lombok Barat dibawah kepemimpinan Fauzan telah mampu meningkatkan angkanya dari 5,69 tahun 2015 menjadi 5,93 tahun 2016, begitu pula dengan harapan lama sekolah yang sangat drastis mengalami peningkatan, dari 12,09 tahun menjadi 12,66 tahun dalam dua tahun berturut-turut.

Bukti keseriusan Fauzan Khalid untuk memperjuangkan nasib para guru terutama yang tidak tetap adalah dengan menyetujui untuk memberikan insentif bagi 770 guru honorer SD, 117 guru honorer SMP, dan 376 operator yang merupakan tenaga pendidkan di Kabupaten Lombok Barat. sejumlahnya berjumlah 1.263 orang yang diberikan insentif tambahan honor dari APBD langsung dan tidak terkait dengan dana BOS sebesar Rp.400.00o guru/ bulan.

Keempat, Pembangunan Infrastrktur, infrsstruktur adalah bagian yang paling menonjol dalam sebuah pembangunan. Semenjak dilantik menjadi Bupati, Fauzan senantiasa memberikan "catatan khusus" kepada infrastruktur yang berbasis pada pelayanan dan kebutuhan publik. Dalam dua tahun kepemimpinan Fauzan, infrastruktur, pendidikan, pusat-pusat pelayanan publik, irigasi serta jalan raya yang menjadi nprioritas yang diarahkan kepada seluruh SKPD terkait untuk dikerjakan. Untuk memenuhi standar pelayanan minimum di bidang kesehatan dasar, dia telah membangun 2 pusat kesehatan masyarakat (Puskesmas) dan Merevitalisasi beberapa Puskesmas Pembantu (Pustu) diberbagi tempat. Demikian pula untuk sktor pendidikan ia sangat antusias mendorong dan menyetujui penggangaran untuk penambahan ruang kelas baru serta fasilitas pendidikan lainnya untuk SD dan SMP dan bahkan khusus buat SMA pada tahun 2016. Fauzan sangat tahu bahwa pembangunan sumber daya manusia adalah yang paling utama selain persoalan ekonomi.

Kelima, Memperkuat Industri Pariwisata. Pariwisata menjadi ujung tombak pemasaran daerah Lombok Barat dapat dikenal keseluruh penjuru nusantara bahkan dunia internasional. Fauzan menyadari efek pariwisata memberikan kontribusi yang cukup signifikan dalam raihan pendapatan Asli Daerah (PAD) dalam APBD di Kabupaten Lombok Barat. untuk tahun 2016 saja, setidaknya lebih dari 60\% PAD Kabupaten Lombok Barat didapatkan dari efek multiflier industri pariwisata.

Fauzan selama kurun waktu dua tahun terakhir memberikan prioritas pengembangan pariwisata dengan memberi penekanan pada empat aspek utama dalam pariwisata, yaitu, pengembangan destinasi, mengiatkan event promosi dan pemasaran, pengembangan seni budaya, dan mengembangkan jaringan serta partisipasi stakholders (SDM) industri pariwisata. Untuk memperkuat posisi pariwisata itu, Pemerintah Kabupaten Lombok Barat berhasil menyusun Peraturan Daerah Nomor 13 tahun 2017 tentang Pariwisata Berkelanjutan. Kabupaten Lombok Barat satu-satunya Kabupaten/Kota di 
Indonesia yang memiliki Peraturan Daerah tentang hal tersebut.

Sebagai seorang kepala daerah Fauzan Khalid menoreh beberapa prestasi penting sebagai figur pemimpin dalam menahkodai Kabupaten Lombok Barat. Berikut dapat dilihat beberapa prestasi itu:

1. Opini Wajar Tanpa Pengecualian (WTP) 3 kali berturut-turut.

Dengan meraih WTP sampai tiga kali berturutturut, setidaknya Fauzan dan jajaran birokrasi di pemerintah Kabupaten Lombok Barat telah berhasil menunjukan kepada semua pihak tentang pemerintahan yang transparan, jujur, dan bertanggung jawab.

2. Anugrah Dana Racka

Kementerian Keuangan Republik Indonesia telah melakukan penilain kepada semua Kabupaten/ Kota Seindonesia tentang efektivitas sistem penggangarannya dan ketepan waktu dalam penyusunan anggaran. Ditengah kesulitan keuangan, Kabupaten Lombok Barat dianggap berprestasi dalam skema pengelolaan yang efektif dan efisien. Ujungnya adalah reward berupa Dana Insentif Daerah (DID) yang untuk tahun 2017 telah diluncurkan sebsar Rp.53 miliar.

3. Anugra FITRA Award untuk Kabupaten Paling Transaran dan Partisipatif.

Forum indonesia untuk transparansi anggaran atau disingkat FITRA adalah Lembaga Swadaya Masyarakat (LSM) yang bersekala nasional. Mereka bergerak di bidang kontrol sosial untuk transparansi proses penganggaran Negara. Di akhir tahun 2016, melakukan survey kepada kurang lebih dari 125 dari hampir 550 Kabupaten /Kota untuk melakukan penilaian terhadap proses penggangaran. memberikan kepada pemerintah Kabupaten Lombok Barat apresiasi berupa FITRA Award karena dianggap sebagai Kabupaten yang menyelenggarakan proses perencanaan pembangunan secara partisipatif dan paling transparan.

4. Anugra Prahita Ekapraya

5. Anugrah ini ditunjukan untuk mengapresiasi komitmen Kepala Daerah terhadap pemberdayaan perempuan dan perlindungan anak. Setelah menetapkan komitmen sebagai "Kabupaten Layak Anak" Fauzan pun meluncurkan gerakan anti Merarik Kodeq (GAMAK) sebagai skema awal perlindungan terhadap anak.

6. Apresiasi itu ditunjukan oleh Kementerian Pemberdayaan Perempuan dan Perlindungan Anak (Kemen PPPA) Republik Indonesia Kepada Fauzan karena diketahui sangat sering mensosialisasikan hal tersebut melalui segala media dan foruupatim.

7. Bupati Inspiratif Versi Majalah "Keuangan Negara"

Fauzan Khalid dinilai memiliki inovasi dan terobosan yang dapat dijadikan best practices dan insprasi bagi Kepala Daerah lain se-Indonesia dalam pembangunan berdaya saing dan peningkatan kualitas pelayanan publik.

8. Kabupaten Paling Potensial Pengembangan Infrastruktur Daerah

Majalah bertaraf nasional terkemuka TEMPO pun tergelitik dengan kiprah Fauzan Khalid dalam mempromosikan daerah di kancah nasioanl. Gelitikan itu menetapkan Kabupaten Lombok Barat sebagai kabupaten yang layak dinilai dari seluruh Kabupaten/Kota seindonesia yang bergerak cepat dalam pembangunan.

\section{SIMPULAN DAN SARAN}

\section{Kesimpulan}

Keberhasilan kepala daerah (Fauzan Khalid) di Kabupaten Lombok Barat dalam menjalankan roda pemerintahanya yaitu: menggunakan gaya kepemimpinan yang selama ini dikenal dengan sebutan gaya Kepemimpinan "Jamaq-jamaq" melahirkan gaya kepemimpinan dan tata kelola pemerintahan yang unik. Tata kelola ini seperti menyentuh hal yang mendasar dari mereka, seperti inisiatif menjadi lebih terbuka, potensi yang berkembang, tradisisi kerja yang inovatif dan berfikir yang "out of box" yang tercermin dalam proses kerja sehari-hari. Dalam manajemen modern, tata kelola sebuah organisasi tidak berpusat pada pemimpin (leader) pemimpin mendelegasikan tugas dan kewenanaganya tetap tetap melakukan pengawasan. Dalam manajemen modern itupun, keputusan tidak hanya datang dari seseorang saja, namun berlaku asas musyawarah yang kolektif dimana keputusan yang diambil adalah didominasi menurut pandangan dari yang akan menjalankan dan ahlinya.

Gaya Kepemimpinan Jamaq-jamaq yang sudah diimplementasikan oleh Fauzan Khalid di Kabupaten Lombok Barat sudah memberikan banyak sekali perubahan-perubahan mulai dari peningkatan Perlakuan Khusus untuk Industri Kecil Menengah, Memperhatikan kesehatan Reproduksi Serta Kesehatan Ibu dan Anak, Mendorong kinerja para tenaga Kependidikan dan Guru Tidak Tetap, Pembangunan Infrastrktur, dan Memperkuat Industri Pariwisata. Selain itu juga melalui gaya Jamaq-jamaq tersebut Fauzan Khalid mampu disejajarkan dengan beberapa kepala daerah lain yang prestasi di Indonesia,seperti: . Opini Wajar Tanpa Pengecualian (WTP) 3 kali berturut-turut, Anugrah Dana Racka, Anugra FITRA Award untuk Kabupaten Paling Transaran dan Partisipatif, Anugra Prahita Ekapraya, Bupati Inspiratif Versi Majalah "Keuangan Negara", dan Kabupaten Paling Potensial Pengembangan Infrastruktur Daerah.

\section{Saran}

a. Mengembangkan gaya kepemimpinan Jamaqjamaq untuk lebih menyentuh kesemua sektor sendi kehidupan masyarakat di Kabupaten Lombok Barat.

b. Lebih memperhatikan tingkat kesejahteraan para guru terutama yang tidak tetap, karena selama ini 
masih belum tersentuh secara maksimal oleh pemerintah.

\section{DAFTAR RUJUKAN}

[1]. Arikunto, Suharsimi, Metodologi Penelitian Suatu Pendekatan Praktik, Jakarta: Rineka Cipta, 2010.

[2]. Delly Mustafa, Birokrasi Pemerintahan, Alfabeta, 2014.

[3]. JIAN UGM dan MAP UGM, Reformasi Birokrasi, Kepemimpinan, dan Pelayanan Publik,Gava Media, Yogyakarta, 2009.

[4]. Komarudin, Hidayat dan M. Yudhi Haryono, Manuver Politik Ulama, Tafsir Kepemimpinan Islam dan Dialektika Ulama, Negara, Jala Setara, Yogyakarta, 2011.

[5]. Lexy J.M. Penelitian Kualitatif, Jakarta: PT. Rineka Cipta,2010

[6]. Mutiarin, Dyah, Arif Zainudin, Manajemen Birkrasi dan Kebijakan, penelusuran konsep dan teori, Pustaka Pelajar, Yogyakarta, 2014.

[7]. Nazir, Metodologi Penelitian. Bandung: Rosdakarya, 2010.

[8]. Rahardjo, Mudjia, Genta Pemikiran Islam dan Humaniora, UIN Maliki Press, 2672011.

[9]. United Nations Development Programme,2002,UNDP and Governance for Sustainable Human Development, New York, UNDP policy paper. See also Goh Ban Lee, Non-Compliance: A Neglected Agenda in Urban Governance, Kuala Lumpur: Institute Sultan Iskandar, 2002.

[10]. Siagian, Filsafat Administrasi. Jakarta, Bumi Aksara, 2004.

[11]. Sedarmayanti, Reformasi Administrasi Publik, Reformasi Birokrasi dan Kepemimpinan Masa Depan, Refika Aditama, Bandung, 2009.

[12]. Quinn Patton, Michael, Metode Evaluasi Kualitatif, Pustaka Pelajar, 2006.

[13]. Sugiono, Metode Penelitian Kombinasi, Alpabeta, 2012.

[14]. World Bank, "Governance and Development", Washington D.C., 1992 sebagaimana dikutip oleh Francois Dreyfus, "What Kind of a Citizen for What Kind of State?" dalam Luc Rouben (ed.) 1999, Citizens and the New Governance: Beyond the New Public Management, Amsterdam, IOS Press, 1992.

[15]. Yudhoyono, Soesilo Bambang Dkk, Good Governance dan Otonomi Daerah Menyongsong AFTA 2003, Prosumen dan FORKOMA-MAP KAGAMA UGM, Yogyakarta, 2002. 